\title{
Histochemical Features of the Extracellular Matrix in Rattus rattus norvegicus Otic Ganglion
}

\author{
Características Histoquímicas de la Matriz Extracelular \\ en el Ganglio Ótico de Rattus rattus norvegicus
}

"M. A. Chagas; "M. A. Babinski; ${ }^{* *}$ M. Abidu-Figueiredo \& ${ }^{* * *}$ W. S. Costa

CHAGAS, M. A.; BABINSKI, M. A.; ABIDU-FIGUEIREDO, M. \& COSTA, W. S. Histochemical features of the extracellular matriz in Rattus rattus norvegicus otic ganglion. Int. J. Morphol., 24(1):77-82, 2006.

SUMMARY: The otic ganglion is a cranial component of the parasympathetic division of the autonomic nervous system (ANS). Similar to other parasympathetic ganglia, otic ganglion presents multipolar neurons that are completely surrounded by satellite cells and intercellular substance as well, which allow us to use this ganglion as a good experimental model for studying the relationship neuron / extracellular matrix. We have studied rat otic ganglion in 10 animals through light microscopy. After routine histological methods, $5 \mu \mathrm{m}$ sections were obtained and coloured by Gomori`s trichrome, periodic acid-Schiff (PAS), Alcian Blue pH 2.5 and pH1.0, acetylation + PAS, acetylation + deacetylation + PAS, acid hydrolysis + PAS, phenylhydrazine + PAS and thiosemicarbazide + PAS. The presence of neutral glycoproteins was demonstrated by PAS reactivity. PAS inhibition following Alcian Blue staining in $\mathrm{pH} 2.5$ and 1.0 showed the presence of a small quantity of acid glycoprotein. The extracellular matrix analysis showed the presence of neutral and acid glycoconjugates. These findings suggests a mutual interaction and a complex role in ganglionic physiology.

KEY WORDS: Rat; Otic ganglion; Autonomic nervous system; Histochemistry.

\section{INTRODUCTION}

Cranial parasympathetic ganglia (otic, ciliary, pterygopalatine and submandibular) have a more pronounced anatomical individuality than the ganglia of the thoracic and abdominal cavities, which are located in the organs' walls. They usually present a plexiform arrangement, and extremely short post-gangliar fibers (Williams et al., 1989; Brodal, 1998).

According to Kuder (1983), the otic ganglia of the rat is located below the sphenoid bone, next to where the mandibular division of the trigeminal nerve makes the foramen oval, being more closely related to the maxillary artery than to the mandibular nerve. It presents a biconvex disk shape, around $0.75 \mathrm{~mm}$ length, $0.94 \mathrm{~mm}$ wide, and $0,30 \mathrm{~mm}$ thick (Kuder; Al-Hadithi \& Mitchell, 1987). This description differs from the one observed in men, whose otic ganglion is sidelong the mandibular division of the trigeminal nerve, posterior to the medium meningeal artery, and medially to the lifting muscle of the palatine veil (Williams et al.; Brodal). Thus, there are no direct relations with the maxillary artery, except in rare variations, in which this artery deeply passes the mandibular nerve (Al-Hadithi \& Mitchell).

Despite the existing studies (Costa et al., 1988; Costa et al., 1991) on the structure, ultrastructure, and stereology analysis of the rat autonomic nervous system (ANS), there are still few articles presenting the extracellular matrix (ECM) of the parasympathetic ganglion, and specially on the otic ganglion.

Generally, the biological meaning of the ECM, and particularly the collagen, was deeply modified during the last decades (Rutka et al., 1988). From inert proteins with a small turnover and static functions, the collagen now consist of a family of proteins associated to other interstitial components (elastic fibers, glycosaminoglycans (GAGs), and non-collagenous glycoproteins), forming molecular compounds which act directly on the cellular recognition, adherence, migration, proliferation, and differentiation processes.

\footnotetext{
* Department of Morphology, Fluminense Federal University (UFF), Niterói, Rio de Janeiro, Brazil.

** Department of Animal Anatomy, Rural Federal University of Rio de Janeiro (UFRRJ), Seropédica, Rio de Janeiro, Brazil.

**** Department of Anatomy, State University of Rio de Janeiro (UERJ), Rio de Janeiro, Brazil.
} 
The present study aims at evaluating, through histochemical methods, the presence of several ECM components of the rat otic ganglion through light microscopy. This assignment is facilitated due to the physiology, the particular anatomic positioning of this ganglion, and its histological formation, as it has (as the other cranial parasympathetic ganglia) abundant intercellular substance. This situation, contrary to the one found in the central nervous system (CNS), allows the use of this ANS segment as an experimental model suitable for the analysis of the matrix/ neuron and matrix/neuroglia interaction.

\section{MATERIAL AND METHOD}

Ten (10) young male Rattus rattus norvegicus (Wistar) animals, weighing between 250 and 300 gr. were used. Animals were previously anaesthetised by inhalation of sulfuric ether, and then submitted to intracardiac perfusion with a 10\% phosphate buffered formalin solution (Bancroft $\&$ Cook, 1994). Afterwards the dissection under stereoscopic microscope was performed, ganglia of 5 animals were placed in the same perfusion fixative and the remaining in the Bouin solution for a period of 6 hours, at the most. The entire ganglion were included in Paraplast (Sigma Chemical Co., P-3683) according to routine histological method, and $5 \mu \mathrm{m}$ sections were obtained from the tissue samples.

The sections were coloured by Gomori's trichrome (1950), periodic acid-Schiff (PAS) (McManus, 1948; Bancroft \& Cook), Alcian Blue Ph 2.5 and Ph1.0 (Pearse, 1985; Bancroft \& Cook), Acetylation + PAS (Pearse), acetylation + deacetylation + PAS (Pearse), acid hydrolysis + PAS (Quintarelli, 1961), periodic acid + phenylhydrazine + Schiff reagent (Bancroft \& Cook), periodic acid + thiosemicarbazide + Schiff reagent (Pearse; Bancroft \& Cook) and observed in an Olympus BH-2 optical microscope.

\section{RESULTS}

In all the sections observed, otic ganglion always showed a homogenous appearance, and composed by a compact aggregate of spheroid neurons wrapped by connective tissue. In the outward, a thin dense fibrous connective tissue capsule stands out (Fig.1), separating the ganglion from surrounding filling tissue and sending delicate septa which individually perycarion involved. Both the capsule and internal septa were stained green by Gomori trichrome technique, suggesting a predominance of collagen fibers.
Through the PAS technique, ganglionic ECM showed an intense PAS+ reaction, which suggests neutral glycoproteins presence. Basal membrane, which is around the perycarion/satellite cells, did not stand out, since the reaction was homogeneous all over the ganglion. PAS method with previous acetylation (Fig. 2) was used to confirm the selectivity of Schiff Reactive, for 1-2 glycol grouping showed to be efficient, as the intensity reaction was softer.

Acid hydrolysis previous to PAS reaction resulting in a clear reduction of PAS positivity in ganglionic ECM, suggesting acid GAGs presence with glycol - periodic acid + phenylhydrazine + PAS grouping (Fig. 3).

Thiosemicarbazide solution used after the sections oxidation by periodic acid, was able to completely block the PAS positivity in ganglionic ECM, confirming aldehyde grouping presence (Fig. 4).

Phenylhydrazine used (Fig. 5) as a specific agent for aldehyde grouping originated from neutral glycoproteins was efficient in ganglionic interstitial space, almost completely reducing PAS positivity.

Alcian Blue method (Fig. 6) was used in a pH 2.5 solution, as this would embrace the characterisation of different sulphated and carboxylated acid GAGs. To gauge intensity reaction, a positive control section using a fragment of hyaline cartilage, rich in acid GAGs was elaborated.

In $\mathrm{pH} 2.5$, ganglionic ECM showed a weak and homogenous reaction, suggesting that ganglionic matrix does not show an expressive level of acid glicoconjugates. In $\mathrm{pH} 1.0$ (Fig. 7) the matrix reactivity was unstable, showing a very weak reaction, or even no existent, which suggests an extremely low proportion of sulphated glicoconjugates.

\section{DISCUSSION}

The ANS ganglia anatomic localisation turns its cells more vulnerable to mechanical trauma actions and pathogenic agents than CNS cells, which is protected by the cranium and meninges (Montes et al., 1984). Therefore, most of the maintenance, nutrition, protection and defense functions of the ganglionic parenchyma and its nervous fibers falls over its connective component, since the specific neuroglia (satellite and Schwann's cells) is little prominent when compared to it. 


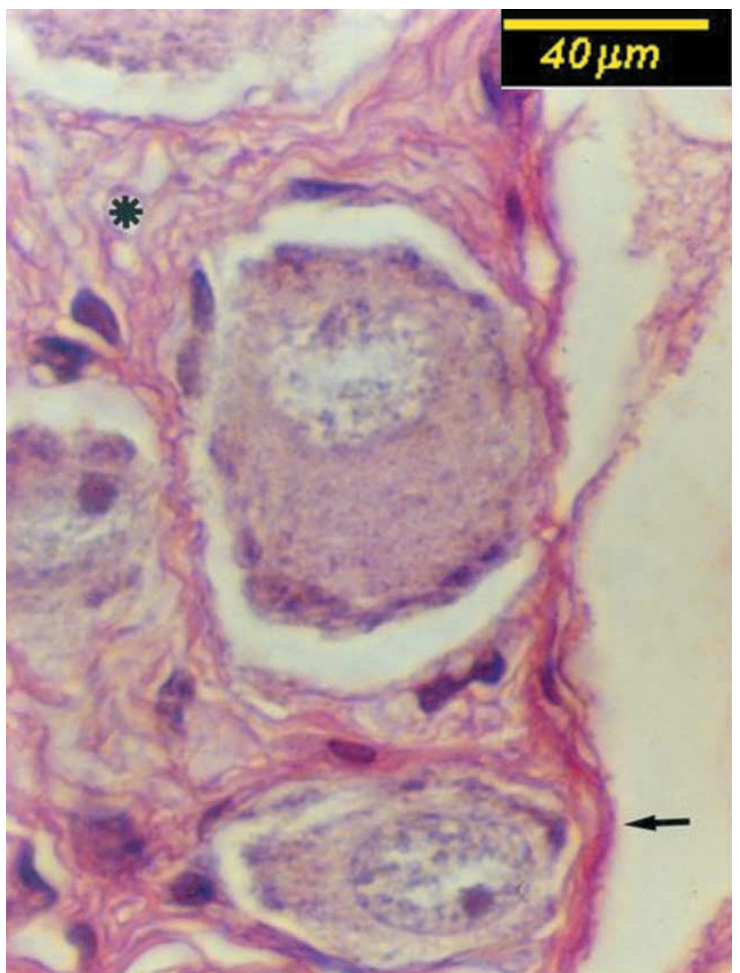

Fig. 1. Ganglion capsule show strongly reaction (arrow). The interstitial connective tissue exhibits a homogeneous stain (asterisk). PAS. 1,000 x.

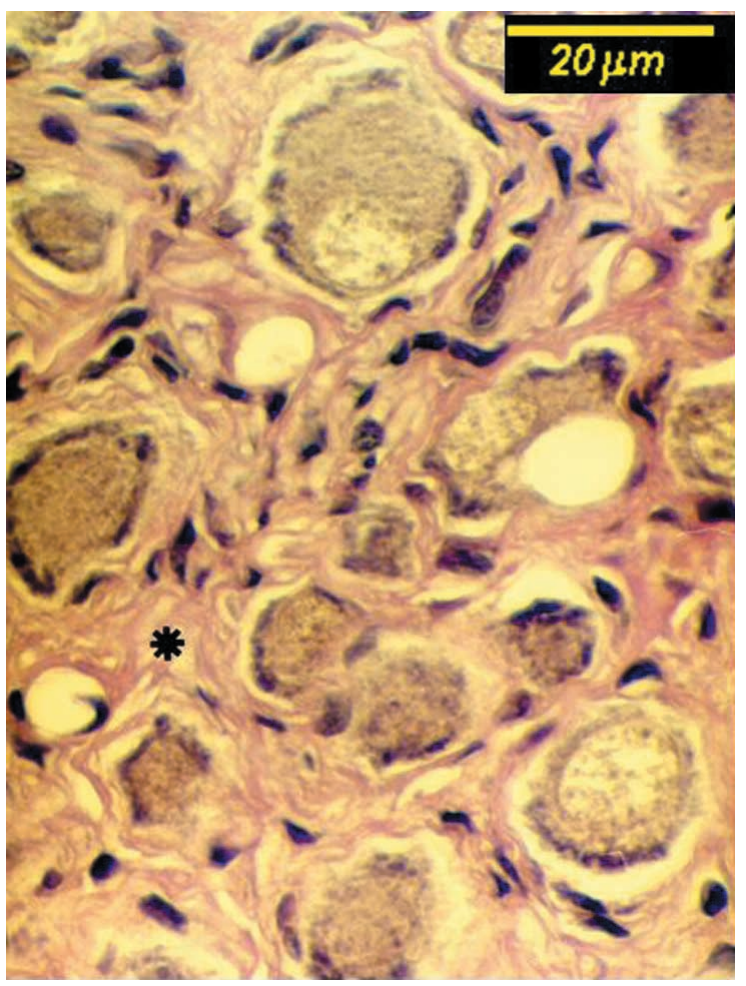

Fig. 3. Connective tissue (asterisk) with weak reactivity. Acid hydrolysis - PAS. $400 \mathrm{x}$.

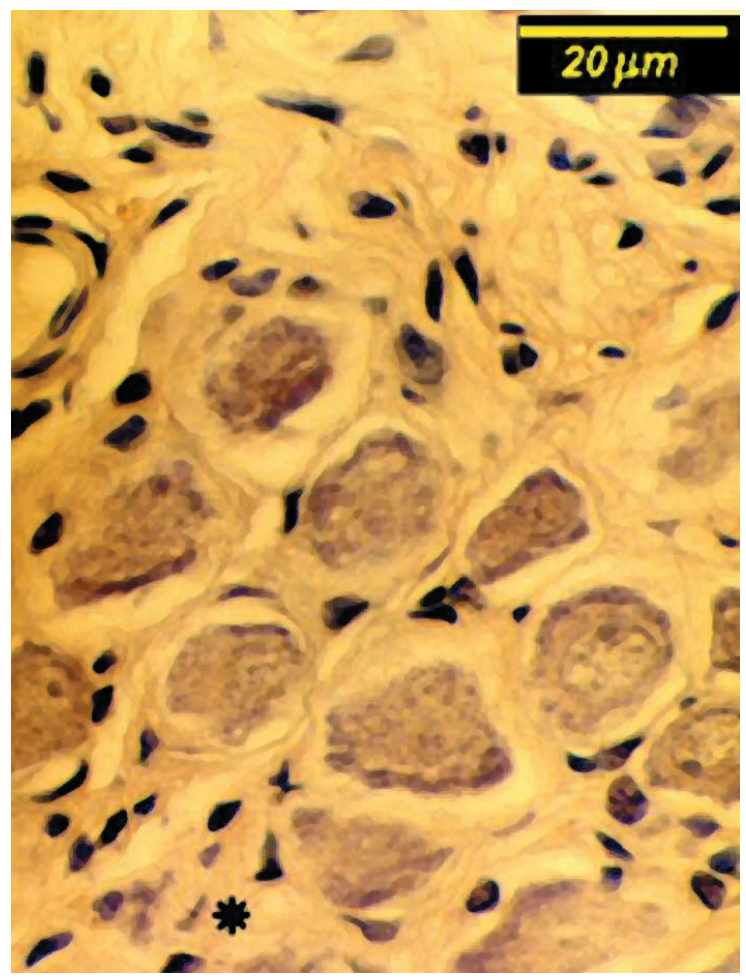

Fig. 2. Ganglionar extracellular matrix (asterisk), weakly stained. Acetylation-PAS. $400 \mathrm{x}$.

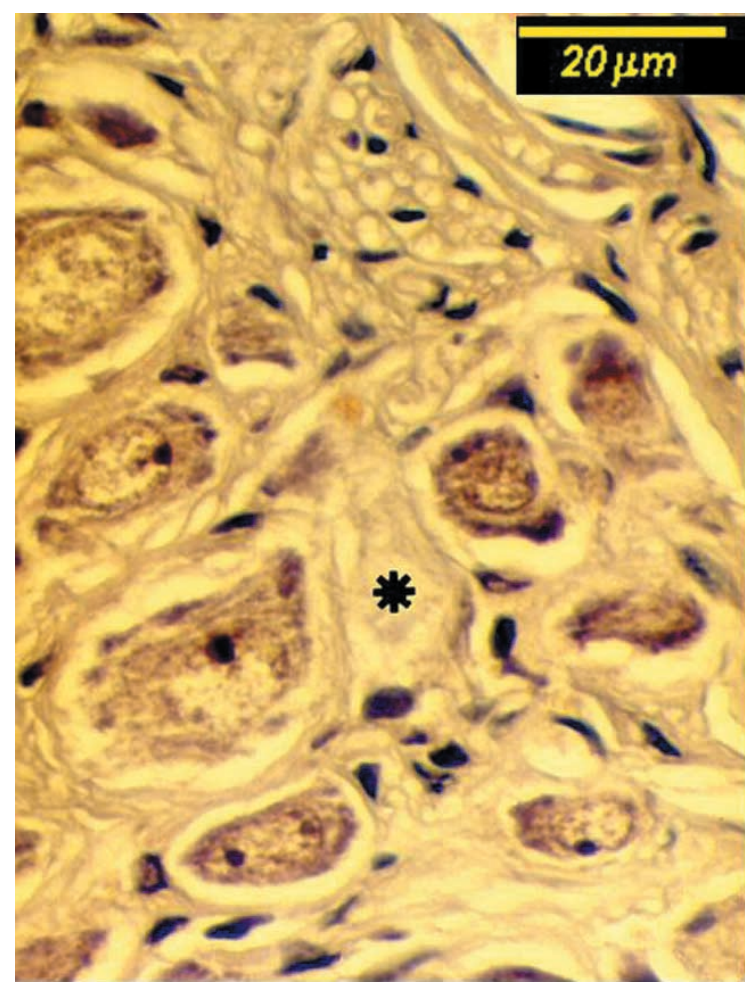

Fig. 4. Ganglionar extracellular matrix (asterisk) show diffuse and pale stained. Thiosemicarbazide-PAS. $400 \mathrm{x}$. 


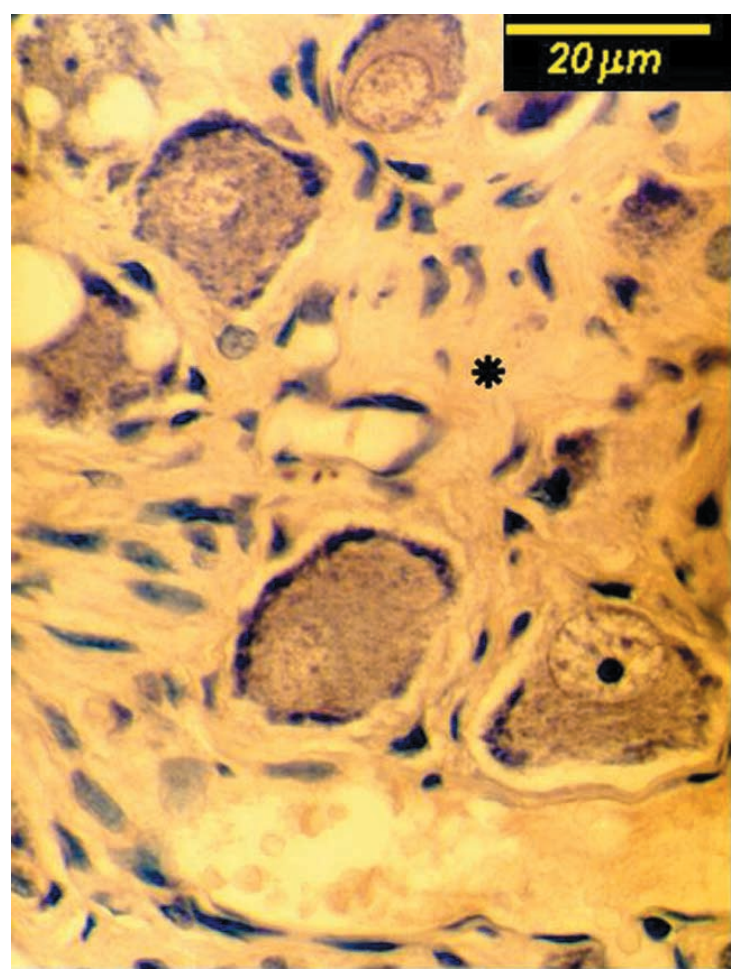

Fig. 5. Interstitial connective tissue (asterisk) with weak reactivity. Phenylhydrazine-PAS. $400 \mathrm{x}$.

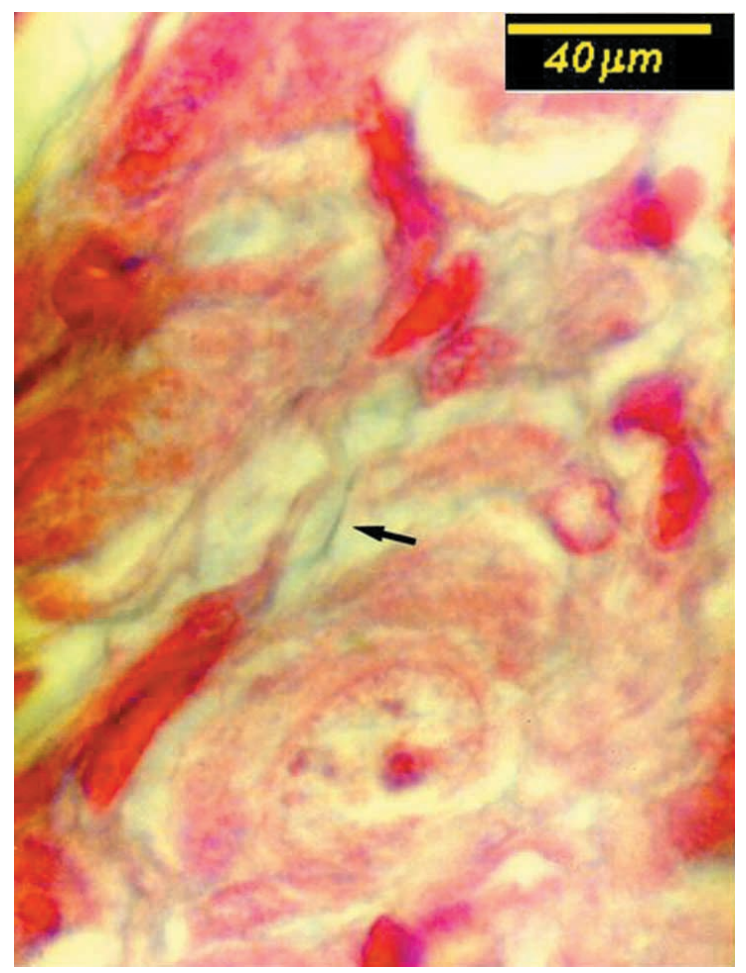

Fig. 7. Delicate filaments show alcian blue affinity (arrow) dispersed inside extracellular matrix network. $\mathrm{AB}(\mathrm{pH} 1,0)$ $1,000 \mathrm{x}$.

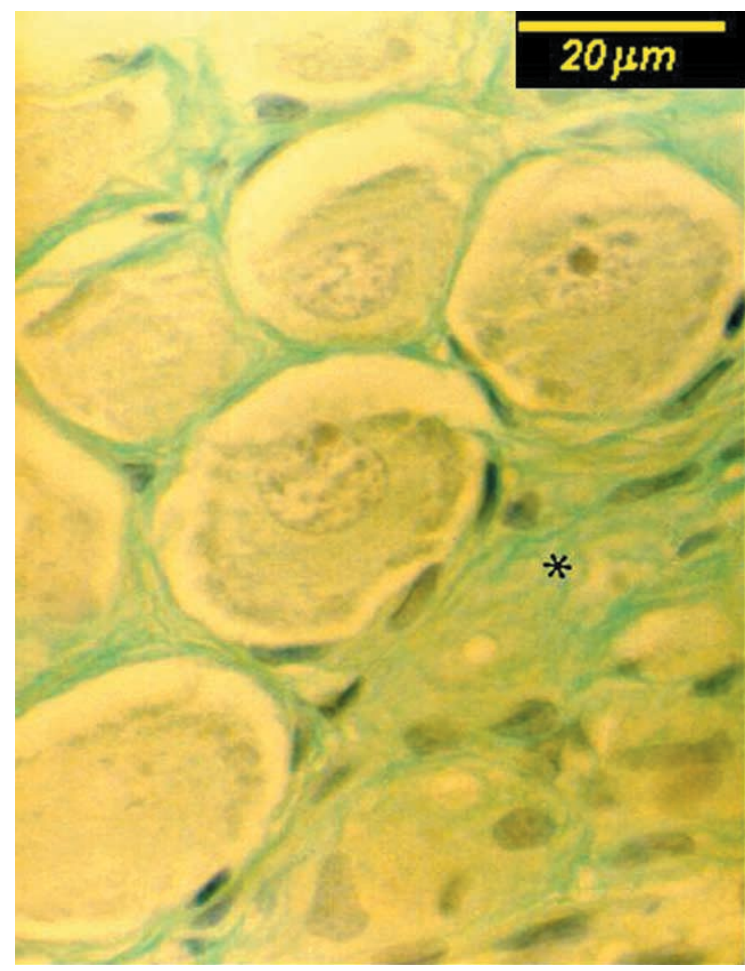

Fig. 6. The intercellular substance showed (asterisk) weakly alcianophilic. AB (pH 2,5) . 400 x.

The strong colouring showed by the ganglionic ECM in the PAS technique suggests the presence of neutral glycoproteins/GAGs in association with the collagen fibers, as these fibers have a weak PAS positivity (Bancroft \& Cook).

The blockade methods of the PAS reaction utilising acetylation and thiosemicarbazide are supplementary. The acetylation which occurred before the sections oxidation by PAS aims at obstructing the 1-2 glycol grouping, avoiding the formation of aldehyde (Pearse). Thus, almost all PAS positivity was eliminated, the glycol grouping seem to act directly in the process. Using the thiosemicarbazide in a subsequent blockade to the oxidation, aiming specially at the aldehyde inactivity, the PAS positivity was again eliminated, confirming the participation of both molecules in the reactions.

The phenylhydrazine addition to PAS method eliminated most of the reactivity, although in a less emphasized way than the acetylation/ tiosemicarbazide techniques. Since phenylhydrazine blocks specially the aldehyde produced by neutral glycoprotein, only the aldehyde formed by sialomucins and sulfomucins remain reactive to PAS (Pearse; Bancroft \& Cook). Therefore, the residual positivity leads us to suppose that there is a small quantity 
of one of these substances, or both of them in the ganglionic ECM.

This assumption was reinforced by the utilisation of a blockade through specific acid hydrolysis for the exclusion of sialic acid, and a reduction in the matrix PAS positivity was observed, which again suggests this molecules group participation in ECM.

Concerning the ganglionic ECM reactivity to Alcian Blue, the discreet $\mathrm{pH} 2.5$ reaction (when compared to a control lamina of hyaline cartilage) suggests a low content of acid GAGs. As this is a standard reaction (Bancroft \& Cook), it is not possible to identify the weakly acid glicoconjugates (usually carboxylate). In $\mathrm{pH} 1.0$, the ECM reaction was extremely weak, even absent in many sections, suggesting a small quantity of strongly acid GAGs. However, it should be pointed out that these results may not reflect the proper situation of the existing GAGs in the ganglion, as they are highly sensitive to the histological fixative action due to their solubility, which may remove them partially from the ECM (Junqueira et al., 1981).
This observation is confirmed by Junqueira et al. findings, which correlated the presence of dermatan sulfate associated to collagen fibril type I. As this is a plentiful type of collagen in the ganglionic ECM, it is supposed that strongly acid GAGs are also present, and do not show a most significant reaction due to the high hydrophily and to the fixative used as well.

From the above findings, it can be concluded that rat otic ganglion ECM shows neutral glicoconjugates, weakly and strongly acid, and possibly sialomucins associated to collagen fibers, suggesting a mutual interaction and a complex role in ganglionic physiology.

\section{ACKNOWLEDGMENTS}

The present study was supported by Grants from the National Council of Scientific and Technological Development (CNPq-Brazil), and from the Foundation for Research Support of Rio de Janeiro (FAPERJ).

CHAGAS, M. A.; BABINSKI, M. A.; ABIDU-FIGUEIREDO, M. \& COSTA, W. S. Características histoquímicas de la matriz extracelular en el ganglio ótico de Rattus rattus norvegicus. Int. J. Morphol., 24(1):77-82, 2006.

RESUMEN: El ganglio ótico es un componente craneal de la división parasimpática del sistema nervioso autónomo (SNA). Similar al otro ganglio parasimpático, el ganglio ótico presenta neuronas multipolares que están rodeadas totalmente por las células satélites y la sustancia intercelular, lo cual permite la utilización de este ganglio como un buen modelo experimental para estudiar las relaciones matriz extracelular/neurona. Examinamos, con microscopio de luz, el ganglio ótico 10 ratones. Con los métodos histológicos rutinarios fueron obtenidas 5 secciones y coloreadas con tricrómico de Gomori, PAS, Azul de Alcián pH 2.5 y pH1.0, acetilación + PAS, acetilación + desacetilación + PAS, hidrólisis de ácido + PAS, fenilhidrazina + PAS y tiosemicarbacida + PAS. La presencia de glicoproteínas neutras fue demostrada por la reactividad de PAS. La inhibición de PAS y la posterior tinción con Azul de Alcian en pH 2.5 y 1.0, demostró la presencia de una cantidad pequeña de glicoproteínas ácidas. El análisis extracelular de la matriz demostró la presencia de glicoconjugados neutros y ácidos. Estos resultados sugieren una interacción mutua y un papel complejo en la fisiología ganglionar.

PALABRAS CLAVE: Rata; Ganglio ótico; Sistema nervioso autónomo; Histoquímica.

\section{REFERENCES}

Al-Hadithi, B. A. K. \& Mitchell, J. The otic ganglion and its neural connections in the rat. J. Anat.,154:113-9, 1987.

Bancroft, J. D. \& Cook, H. C. Manual of Histological Techniques and their Diagnostic Application. Edinburgh, Churchill Livingstone, 1994.

Brodal, P. The central nervous system: structure and function. $2^{\text {th }}$ ed. New York, Oxford, 1998.

Costa, W. S.; Mandarim-de-Lacerda, C. A. \& Bauer, J. A. Fine structure and quantitative study in the otic ganglia of the rat. Gegenbaurs Morphol. Jahrb., 134(6):949-55, 1988.

Costa, W. S.; Mandarim-de-Lacerda, C. A. \& Bauer, J. A. Stereological analisys of the otic ganglia in adult rat: light microscopic study. Anat. Anz., 172:203-7, 1991.

Gomori, G. A rapid one-step trichrome stain. Am. J. Clin. Pathol., 20:661, 1950.

Junqueira, L. C. U.; Toledo, O. M. S. \& Montes, G. S. Correlation of specific sulfated glycosaminoglycans with 
collagen types I, II and III. Cell Tissue Res., 217:171-5, 1981.

Kuder, T. Comparative morphology and topography of cranial parasympathetic ganglia connected with the trigeminal nerve in mouse, rat and hamster. Part I. Otic ganglion. Folia Morphol (Warsz)., 42(3):187-97, 1983.

McManus, J. F. A. Histological and histochemical uses of periodic acid. Stain Technol., 23:99-108, 1948.

Montes, G. S.; Cotta-Pereira, G. \& Junqueira, L. C. U. The connective tissue matrix of the vertebrate peripheral nervous system. Advances in Cellular Neurobiology, 5: 177-218, 1984.

Pearse, A. G. E. Histochemistry - Theoretical and Applied. $4^{\text {th }}$ ed. Edinburgh, Churchill Livingstone, 1985.

Rutka, J. T.; Apodaca, G.; Stern, R. \& Rosenblum, M. The extracellular matrix of the central and peripheral nervous systems: structure and function. J. Neurosurg., 69:15570, 1988.

Quintarelli, G. Histochemistry of sialo-mucins in connective tissues. Histochemie, 2:356, 1961.

Williams, P.; Warwick, R.; Dyson, M. \& Bannister, L.H. Gray's Anatomy. $37^{\text {th }}$. London, Churchill Livingstone, 1989. V. 1.pp. 599.
Correspondence to:

Prof. Dr. Mauricio Alves Chagas $\mathcal{D} \mathcal{V} \mathcal{M}$, PhD

Departamento de Morfologia,

Instituto Biomédico,

Universidade Federal Fluminense (UFF),

Rua Ernani Mello, 101, São Domingos,

CEP 24.210-150,

Niterói, $\mathcal{R}$,

BRAZIL

Fax: (55) (21) 2629-2414.

Fax : (21) 2587-6121

E-Mail:chagas_m@vm.uff.6r

chagas.m@gmal.com

Received: 30-11-2005

Accepted: 16-01-2006 